Check for updates

Cite this: RSC Adv., 2019, 9, 7203

Received 24th January 2019 Accepted 25th February 2019

DOI: 10.1039/c9ra00616h

rsc.li/rsc-advances

\section{Direct synthesis of 2-oxo-acetamidines from methyl ketones, aromatic amines and DMF via copper-catalyzed $\mathrm{C}\left(\mathrm{sp}^{3}\right)-\mathrm{H}$ amidination $\uparrow$}

\author{
Dianke Xie, (D) Wei He, Jiang Xiao, Yao Wu, Yongjia Guo, Qiang Liu* \\ and Cancheng Guo*
}

A convenient method for the synthesis of 2-oxo-acetamidines from methyl ketones using aromatic amines and DMF as nitrogen sources is reported via copper-catalyzed $\mathrm{C}\left(\mathrm{sp}^{3}\right)-\mathrm{H}$ amidination. Various methyl ketones react readily with aromatic amines and DMF, producing 2-oxo-acetamidines in yields of 47 to 92\%. This protocol features the simultaneous formation of $\mathrm{C}-\mathrm{N}$ and $\mathrm{C}=\mathrm{N}$ bonds using $\mathrm{DMF}$ and aromatic amines as two different nitrogen sources. It thus provides an efficient approach to construct acyclic amidines via three $\mathrm{C}\left(\mathrm{sp}^{3}\right)-\mathrm{H}$ bond amidination. Based on the preliminary experiments, a plausible mechanism of this transformation is disclosed.

\section{Introduction}

Amidines are important structural motifs in natural products, bioactive molecules and functional materials. ${ }^{1}$ They have profound applications in diverse areas such as medicinal chemistry, synthetic intermediates, catalyst design, material science, supramolecular chemistry, and coordination chemistry. ${ }^{2}$ Therefore, the direct and convenient construction of amidines is an important and popular research field, particularly for the synthesis of 2-oxo-acetamidines due to the wide applications of their carbonyl group as a versatile intermediate in the synthesis of a broad range of acetamidine derivatives. ${ }^{3}$ Recently, transition metal and metal-free catalyzed $\mathrm{C}-\mathrm{N}$ bond formation has arisen as an excellent synthetic method to build complex structures because it reduces prefunctionalization while improving atom economy and energy efficiency. ${ }^{4}$ These protocols used nitriles, ${ }^{5}$ isonitriles, ${ }^{6}$ organic azides, ${ }^{7}$ and amines $^{8}$ as nitrogenous sources, which are considered important pathways to construct cyclic and acyclic amidines.

Amides are key building blocks of proteins and are broadly found in natural and manufactured organic molecules. ${ }^{9}$ Meanwhile, amides are also often used as precursor molecules to synthesize amidines..$^{10}$ The general method of synthesizing amidines by amides is mainly divided into the following two strategies: (1) direct amidination of the amide and amine scaffolds without decarbonylation of amide, providing cyclic amidines as the final product (eqn (a)-(c) in Scheme 1); ${ }^{10}(2)$

State Key Laboratory of Chemo/Biosensing and Chemometrics, College of Chemistry and Chemical Engineering, Hunan University, Changsha, 410082, P. R. China. E-mail: fqiangliu@qq.com; ccguo@hnu.edu.cn

$\dagger$ Electronic supplementary information (ESI) available. See DOI: 10.1039/c9ra00616h decarbonylation of the amide to semicyclic amidines (Scheme 1, eqn (d)). ${ }^{11}$ Although significant progress has been made in this field, direct and efficient methods for the synthesis of acyclic amidines from amide are still highly desired.

As our continuing interest in carbon-nitrogen coupling fields, ${ }^{12}$ and inspired by the above-mentioned studies, we herein report a copper-catalyzed adimination of methyl ketones, aromatic amines and DMF to acyclic amidines, 2-oxoacetamidines (Scheme 1, eqn (e)). Even though the reactions of methyl ketones with amines or amides are known to achieve the synthesis of $\alpha$-ketoamides by using metal and metal-free approaches,$^{13}$ the synthesis of acyclic amidines using amides and aromatic amines as two different nitrogen sources has not been described previously. This approach allows direct amidination of three $\mathrm{C}\left(\mathrm{sp}^{3}\right)-\mathrm{H}$ bonds and affords $\mathrm{C}-\mathrm{N}$ bond and $\mathrm{C}=\mathrm{N}$ bond simultaneously. This protocol provides a versatile approach to 2-oxo-acetamidines with good functional group

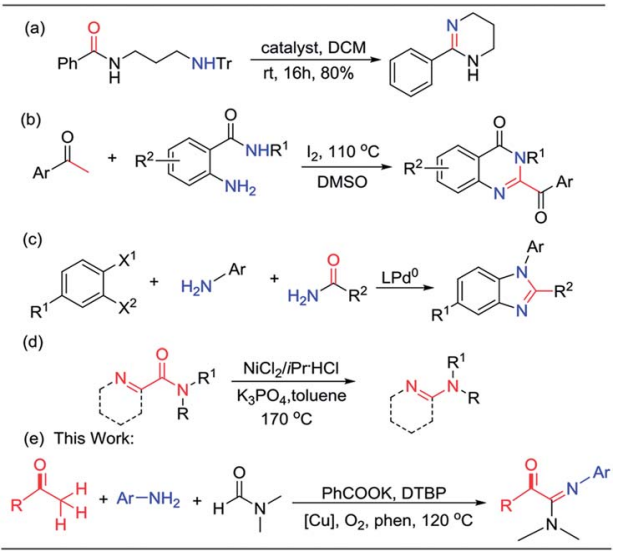

Scheme 1 Methods for the synthesis of amidines. 
Table 1 Optimization of the reaction conditions ${ }^{a}$

\begin{tabular}{|c|c|c|c|c|c|c|}
\hline 1 & $\mathrm{CuCl}_{2}(20)$ & PhCOOK & DMF & DTBP(4) & 120 & 75 \\
\hline 2 & $\mathrm{CuCl}_{2}(20)$ & PhCOOK & DMF & ТВНP(4) & 120 & 15 \\
\hline 3 & $\mathrm{CuCl}_{2}(20)$ & PhCOOK & DMF & $\mathrm{BPO}(4)$ & 120 & 0 \\
\hline 4 & $\mathrm{CuCl}_{2}(20)$ & PhCOOK & DMF & $\operatorname{AIBN}(4)$ & 120 & 0 \\
\hline $5^{c}$ & $\mathrm{CuCl}_{2}(20)$ & PhCOOK & DMF & DTBP(4) & 120 & 85 \\
\hline 6 & & PhCOOK & DMF & DTBP(4) & 120 & 0 \\
\hline 9 & $\mathrm{CuCl}(20)$ & PhCOOK & DMF & DTBP(4) & 120 & 56 \\
\hline 10 & $\mathrm{CuBr}(20)$ & PhCOOK & DMF & DTBP(4) & 120 & 23 \\
\hline 11 & CuI (20) & PhCOOK & $\mathrm{DMF}$ & DTBP(4) & 120 & 19 \\
\hline 12 & $\mathrm{Cu}(\mathrm{OAc})_{2}(20)$ & PhCOOK & DMF & DTBP(4) & 120 & 50 \\
\hline 13 & $\mathrm{Cu}(\mathrm{acac})_{2}(20)$ & PhCOOK & DMF & DTBP(4) & 120 & 47 \\
\hline 14 & $\mathrm{CuCl}_{2}(20)$ & PhCOONa & DMF & DTBP(4) & 120 & 60 \\
\hline 19 & $\mathrm{CuCl}_{2}(20)$ & PhCOOK & DMF & $\operatorname{DTBP}(4)$ & 100 & 50 \\
\hline 20 & $\mathrm{CuCl}_{2}(20)$ & PhCOOK & DMF & DTBP(4) & 140 & 71 \\
\hline $21^{f}$ & $\mathrm{CuCl}_{2}(20)$ & PhCOOK & DMF & DTBP(4) & 120 & 55 \\
\hline $22^{g}$ & $\mathrm{CuCl}_{2}(20)$ & PhCOOK & DMF & $\operatorname{DTBP}(4)$ & 120 & 74 \\
\hline
\end{tabular}

${ }^{a}$ Reaction conditions: 1a $(0.5 \mathrm{mmol}), 2 \mathrm{a}(0.5 \mathrm{mmol})$, catalyst $(0.1 \mathrm{mmol})$, and base $(0.5 \mathrm{mmol})$, oxidant, additive and solvent $(2 \mathrm{~mL})$ under $\mathrm{O}_{2}$ atmosphere at $120{ }^{\circ} \mathrm{C}$ for $36 \mathrm{~h} .{ }^{b}$ Isolated yields. ${ }^{c}$ Phen $(0.1 \mathrm{mmol}) .{ }^{d}$ Air. ${ }^{e} \mathrm{~N}_{2}$ atmosphere. ${ }^{f} 12 \mathrm{~h} .{ }^{g} 24 \mathrm{~h}$. DTBP $=$ di-tert-butyl peroxide, TBHP $=$ tert-butyl hydroperoxide, $\mathrm{BPO}=$ benzoyl peroxide, AIBN $=2,2^{\prime}$-azobis(2-methylpropionitrile), phen $=1,10$-phenanthroline monohydrate, $\mathrm{DMSO}=$ dimethyl sulfoxide, $\mathrm{DMF}=N, N$-dimethylformamide, $\mathrm{THF}=$ tetrahydrofuran.

tolerance. Notably, less reactive aliphatic methyl ketone could also be converted into the corresponding amidine derivatives.

\section{Results and discussion}

Initially, the reaction of acetophenone $\mathbf{1 a}$, aniline $\mathbf{2 a}$ and DMF catalyzed by copper salts was performed to optimize the reaction conditions. The results were listed as shown in Table 1. To our delight, under $\mathrm{CuCl}_{2}$ conditions, reaction of 1a, 2a with DMF afforded mainly oxidative amidination product 4aa in 15$85 \%$ yield (entries $1-8$, Table 1). Subsequently, a number of other oxidants including DTBP, TBHP, BPO, AIBN were explored. Only the DTBP and TBHP effected the reaction, among which DTBP proved to be superior oxidant, giving 4aa in $75 \%$ yield (entries 1-4; Table 1). Gratifyingly, further improvement of the process was achieved when the reaction conducted under the ligand of phen (1,10-phenanthroline monohydrate), affording 4 aa in $85 \%$ yield (entry 5 ; Table 1). Copper salts exhibited unique ability in this transformation, as the reaction did not occur without copper catalyst (entry 6; Table 1). After a series of copper salts were tested (entries 9-13; Table 1), $\mathrm{CuCl}_{2}$ was demonstrated to be the best choice. Further studies indicated that base can promote this transformation, PhCOOK is optimal (entries 14-17; Table 1). Under the nitrogen atmosphere, 1a and 2a could not react to form 4aa (entry 8; Table 1). This fact implied that oxygen was essential for this reaction. Reaction temperature and reaction time were also scanned to improve the yield, and $120^{\circ} \mathrm{C}$ and $36 \mathrm{~h}$ were determined as optimum for the oxidative amidination reaction (entries 18-22; Table 1). After screening on different parameters, the highest yield of $\mathbf{4 a a}(85 \%)$ was achieved when the reaction was carried out with $\mathrm{CuCl}_{2}(0.1 \mathrm{mmol})$, phen $(0.1$ mmol), PhCOOK $(0.5 \mathrm{mmol})$ and DTBP $(2 \mathrm{mmol})$ at $120{ }^{\circ} \mathrm{C}$ under the atmosphere of oxygen in DMF (entry 9; Table 1).

With the optimized reaction conditions in hand, the scope with respect to the methyl ketones was firstly evaluated (Table 2). A wide variety of methyl ketones bearing electron-donating and electron-withdrawing functional groups gave the corresponding products in moderate to excellent yields (4aa-4ra). The position of the substituents on the aryl ring had a minor effect on the efficiency of this transformation. For example, not only methyl ketones 1d and 1i possessing para substituents but also substrates $(\mathbf{1 c}, \mathbf{1 e})$ and $\mathbf{1 b}$, bearing substituents in meta and ortho position, afforded the corresponding products in good yields. In addition, our newly developed protocol tolerated a variety of functionalities, including halogens (4ea, 4fa, 4ga and 4ha), methoxy (4ka), ethoxy (4la), ester groups (4ma), $t$-butyl (4na). Notably, reactive primary amine on the aromatic ring were also 
Table 2 Scope of methyl ketones ${ }^{a}$

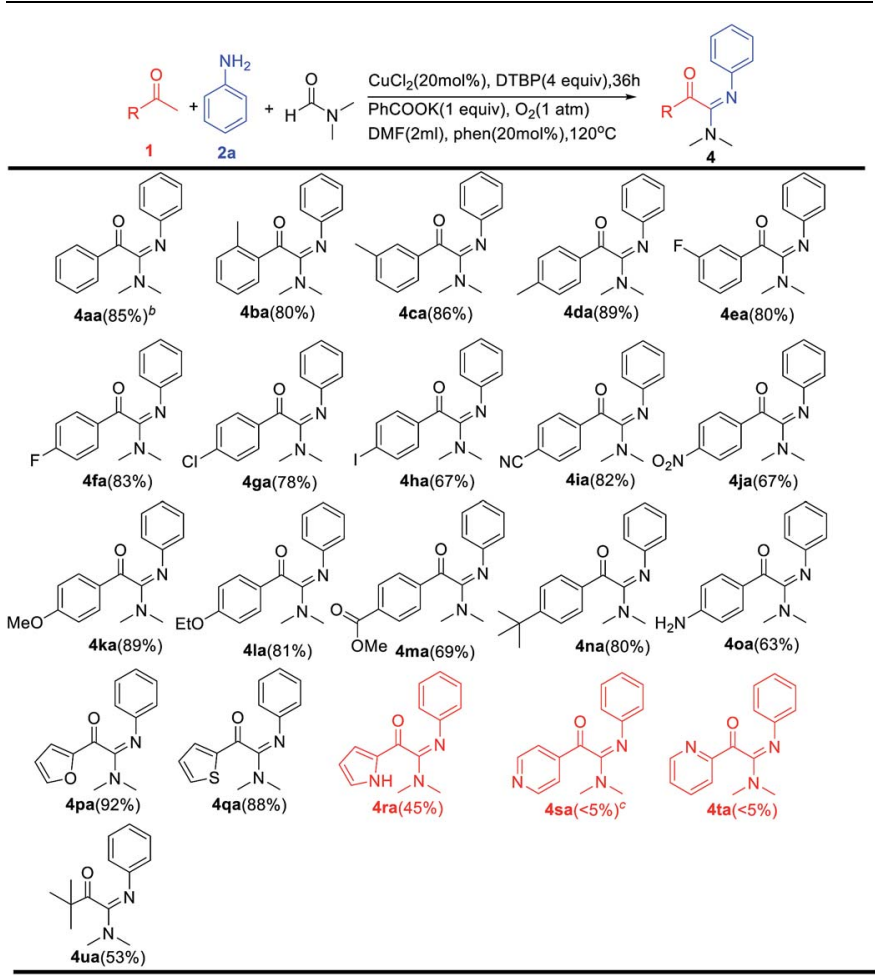

${ }^{a}$ Reaction conditions: $1 \mathrm{a}(0.5 \mathrm{mmol}), 2 \mathrm{a}(0.5 \mathrm{mmol}), \mathrm{CuCl}_{2}(0.1 \mathrm{mmol})$, PhCOOK (0.5 mmol), DTBP (2 mmol), phen (0.1 mmol), $N, N$ dimethylformamide $(2 \mathrm{~mL}), \mathrm{O}_{2}(1 \mathrm{~atm}), 36 \mathrm{~h}, 120{ }^{\circ} \mathrm{C} .{ }^{b}$ Isolated yields. ${ }^{c} \mathrm{GC}$ yields.

tolerated (4oa). Fortunately, when $p$-nitroaniline were used as substrates, the desired products were detected $(\mathbf{4 j a})$ in moderate yield. Heteroaryl methyl ketones were also investigated, and the corresponding products were obtained in moderate to excellent yields (4pa, 4qa, 4ra). Pyridine methyl ketones failed to participate in the reaction to obtain the desired product (4sa,4ta). Moreover, this methodology could be extended to alkyl methyl ketones as well, although in moderate yield (4ua).

Next, the scope of aromatic amines was explored (Table 3). A wide range of structurally diverse aromatic amines were suitable substrates for this transformation. For example, aryl amines bearing methyl groups could generate the corresponding 2-oxo-acetamidines $\mathbf{4 a b - 4 a d}$ in excellent yields. Under the optimal reaction conditions, the meta-halogen substrates (4ae4ag) and the para-halogen substrates (4ah-4ak) are both completely tolerated. Also, functional groups such 4-isopropyl (4am), 3,5-dimethoxy (4an) were well tolerated under our reaction conditions. Fortunately, when $p$-nitroaniline were used as substrates, the desired products were detected (4al) in moderate yield. Moreover, heteroaryl amines were also investigated, and the corresponding products were obtained in moderate yields (4ao,4ap). Unfortunately, pyridin-2-amine and 5methylisoxazol-3-amine are not prone to this reaction (4aq,4ar). Meanwhile, quinolin-8-amine does not react (4as).
Table 3 Scope of aromatic amines ${ }^{a}$

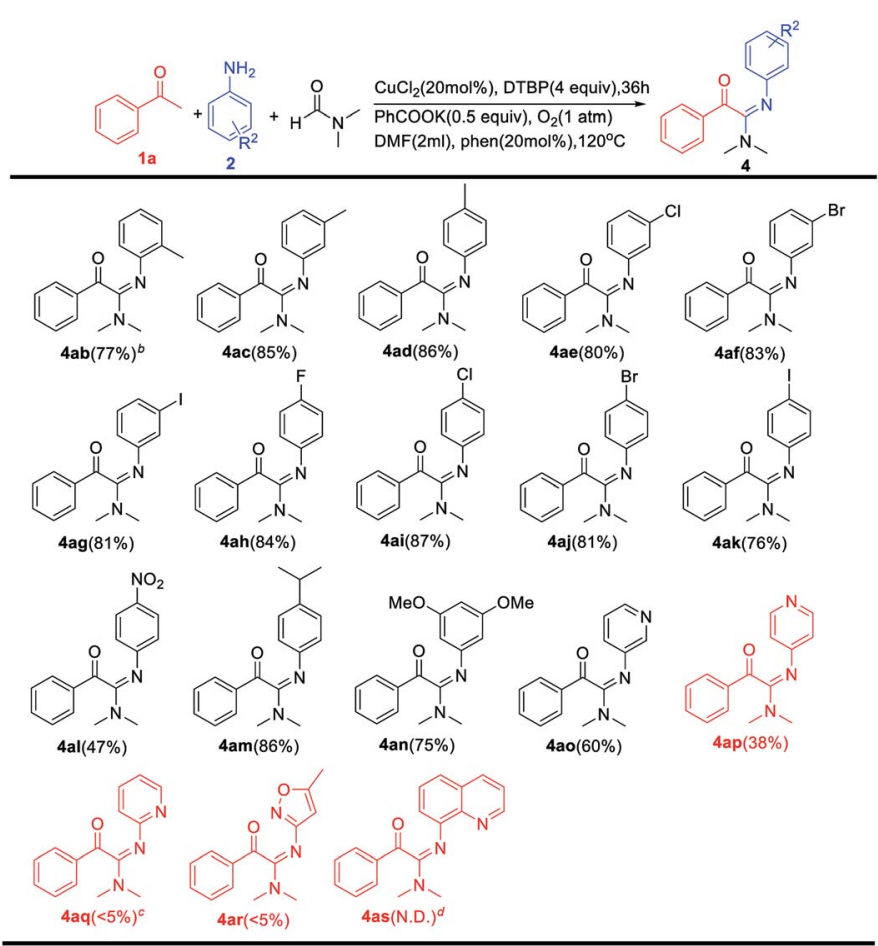

${ }^{a}$ Reaction conditions: $1 \mathrm{a}(0.5 \mathrm{mmol}), 2 \mathrm{a}(0.5 \mathrm{mmol}), \mathrm{CuCl}_{2}(0.1 \mathrm{mmol})$, PhCOOK (0.5 mmol), DTBP $(2 \mathrm{mmol})$, phen $(0.1 \mathrm{mmol}), N, N$ dimethylformamide $(2 \mathrm{~mL}), \mathrm{O}_{2}(1 \mathrm{~atm}), 36 \mathrm{~h}, 120{ }^{\circ} \mathrm{C} .{ }^{b}$ Isolated yields. ${ }^{c}$ GC yields. ${ }^{d}$ N.D. $=$ not detected.

Then, the scope of amides was explored (Table 4). Unfortunately, this protocol was not general to a wide range of formamides including $\mathrm{N}, \mathrm{N}$-diethylformamide, $\mathrm{N}$-methylformamide, $N$-methyl- $N$-phenylformamide, morpholine-4-carbaldehyde with piperidine-1-carbaldehyde, giving no desired products.

To elucidate the mechanism, some control experiments were performed (Scheme 2). At first, the reaction of acetophenone 1a with aniline $2 \mathbf{a}$ was carried out without $\mathrm{CuCl}_{2}$, and the desired product 4aa was not detected (Scheme 2 [eqn (1)]). When the reaction was done in the absence of $\mathrm{O}_{2}$, 4aa was also not detected (Scheme 2 [eqn (1)]). These results suggested that both $\mathrm{CuCl}_{2}$ and $\mathrm{O}_{2}$ were necessary for the reaction. When 2.0 equiv. of BHT (2,6-di-tert-butyl-4methylphenol) was added under the standard conditions, the reaction was inhibited substantially (Scheme 2 [eqn (1)]). The result suggests that the reaction may involve a radical reaction. Our reaction may be involved dimethylamine generated in situ from DMF. ${ }^{14}$ To verify this pathway, dimethylamine 5 was then used instead of DMF under the same conditions (Scheme 2 [eqn (2)]), and only a little amount of 4 aa was detected. This result implies that an aminyl radical, not an amine, was the intermediate in the transformation process. According to the literatures and experimental results, ${ }^{15}$ we predicted that acetophenone 1a may be oxidized to phenylglyoxal intermediate, and then form Schiff base to complete the transformation process. Therefore, we conducted a control experiment in which phenylglyoxal monohydrate 6 and imine 7 


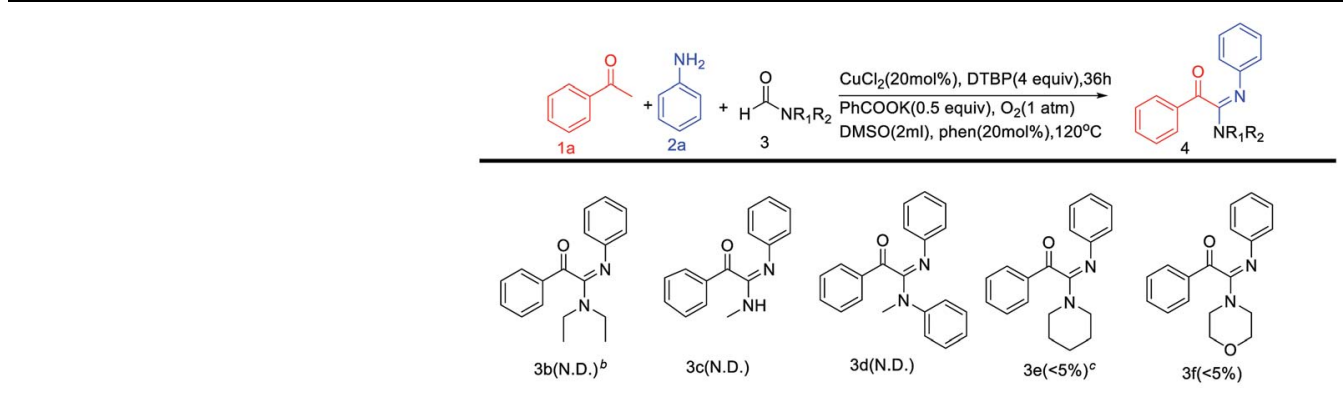

\footnotetext{
${ }^{a}$ Reaction conditions: $1 \mathrm{a}(0.5 \mathrm{mmol}), 2 \mathrm{a}(0.5 \mathrm{mmol}), \mathrm{CuCl}_{2}(0.1 \mathrm{mmol}), \mathrm{PhCOOK}(0.5 \mathrm{mmol}), \mathrm{DTBP}(2 \mathrm{mmol}), \mathrm{phen}(0.1 \mathrm{mmol}), \mathrm{DMSO}(2 \mathrm{~mL}), \mathrm{O}_{2}(1 \mathrm{~atm})$,
} $36 \mathrm{~h}, 120^{\circ} \mathrm{C} .{ }^{b}$ N.D. $=$ not detected. ${ }^{c}$ GC yields.

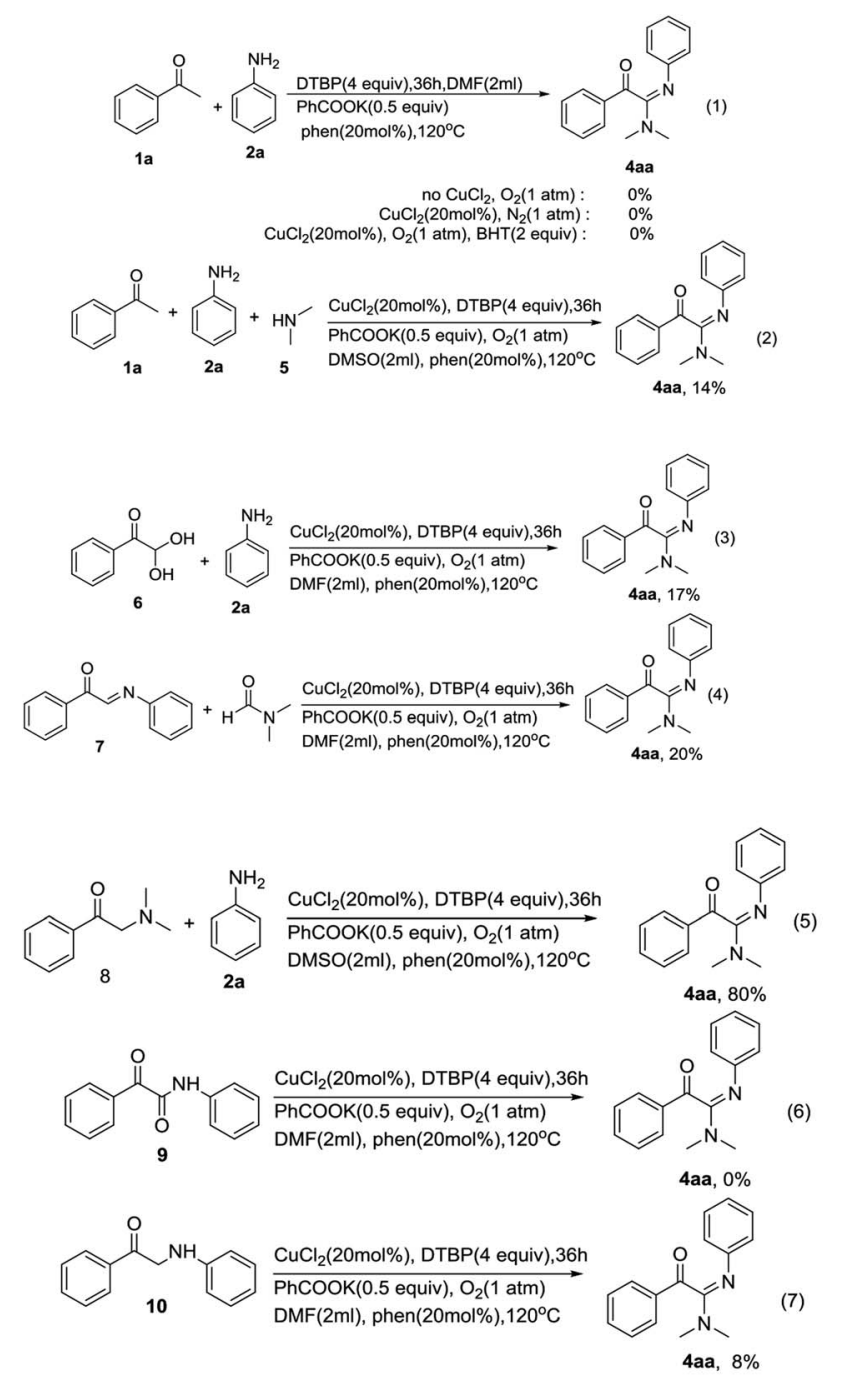

(8)

Scheme 2 Different control experiments. were used as substrates under standard conditions (Scheme 2 [eqn (3) and (4)]). The experimental results show that the target product is obtained in a lower yield, indicating that 6 and 7 may not be the key intermediates in the reaction. As shown in eqn (5), the reactions between 2a and 2-(dimethylamino)-1-phenylethan-1-one 8 were investigated. Under the optimized conditions, the product 4 aa could be furnished in $80 \%$ yields (Scheme 2 [eqn (5)]). The results demonstrated that the reaction may have undergone 8 intermediate process. Notably, 2-oxo-N,2-diphenylacetamide 9 and 1-phenyl-2(phenylamino)ethan-1-one $\mathbf{1 0}$ both were not suitable substrates for the reaction (Scheme 2 [eqn (6) and (7)]]. When the reaction was carried out in the absence of acetophenone 1a, $N, N$-dimethyl- $N^{\prime}$ phenylformimidamide $\mathbf{1 1}$ and 1,2-diphenyldiazene $\mathbf{1 2}$ were detected (Scheme 2 [eqn (8)]). This result indicated the cationic aniline radicals maybe formed in this reaction. ${ }^{16}$

On the basis of the above results, a plausible mechanism for the copper-catalyzed aerobic oxidative coupling is illustrated in Scheme 3. In the first step, the tert-butoxyl radicals trapped hydrogen from the aryl methyl ketone and DMF respectively to form radical $\mathbf{B}^{13 b, 17}$ and aminyl radical $\mathbf{A} .{ }^{18}$ Then, decarboxylation of $\mathbf{A}$ produced aminyl radical $\mathbf{C}$, which reacted with radical $\mathbf{B}$ to generate intermediate $\mathbf{D}$. D was then

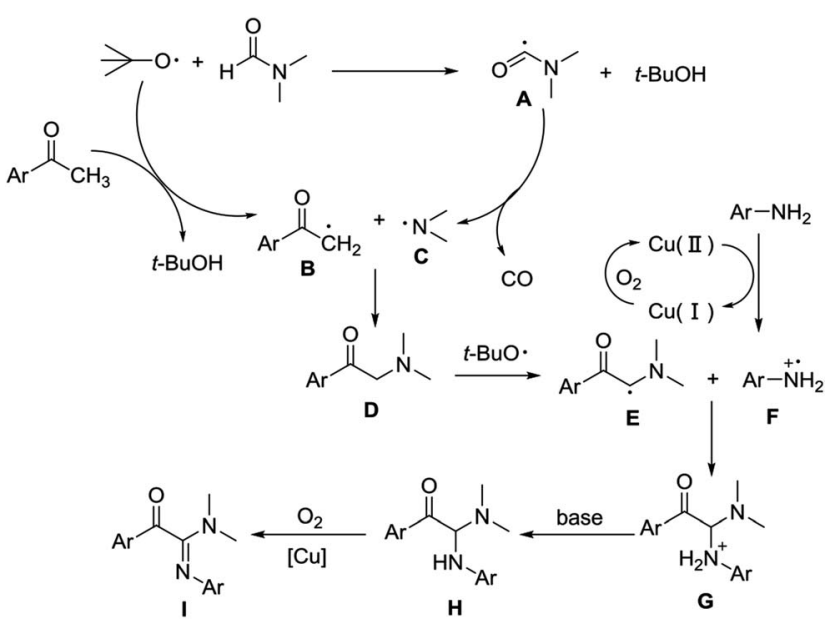

Scheme 3 A proposed mechanism for the direct transformation. 
converted to $\mathbf{E}$ in the presence of tert-butoxyl radical. Meanwhile, a single-electron oxidation of anilines mediated by $\mathrm{Cu}(\mathrm{II})$ occurred, affording corresponding radical cations $\mathbf{F}^{\mathbf{1 6}}$ Cationic radical $\mathbf{F}$ coupled with radical $\mathbf{E}$ to obtain $\mathbf{G}$. Hydrogen ion of $\mathbf{G}$ was removed by base to give the product $\mathbf{H}$. Finally, $\mathbf{H}$ is oxidized under standard conditions to form the desired product I (Scheme 3).

\section{Conclusions}

In conclusion, the copper-catalyzed oxidative amidination of methyl ketones with aromatic amines and DMF has been developed. Acyclic 2-oxo-acetamidines could be obtained with moderate to good yields. This protocol features with acyclic amidines formation using DMF and aromatic amines as two different nitrogen sources. Further investigations on reaction scope and synthetic application are underway in our laboratory.

\section{Conflicts of interest}

There are no conflicts to declare.

\section{Acknowledgements}

This work was financially supported by the National Natural Science Foundation of China (21372068, 21572049), Science and Technology Program of Hunan Province, China (2014GK3115) and Science and Technology Program of Changsha, China (K1508004-11).

\section{Notes and references}

1 (a) R. J. Young, Bioorg. Med. Chem. Lett., 2000, 10, 597; (b) E. M. Stone, T. H. Schaller, H. Bianchi, M. D. Person and W. Fast, Biochemistry, 2005, 44, 13744; (c) R. G. Doveston, R. Steendam, S. Jones and R. J. K. Taylor, Org. Lett., 2012, 14, 1122; (d) C. Maccallini, A. Patruno, N. Besker, J. Ali, A. Ammazzalorso, B. D. Filippis, S. Franceschelli, L. Giampietro, M. Pesce and M. Reale, J. Med. Chem., 2009, 52, 1481; (e) C. Maccallini, A. Patruno, F. Lannutti, M. Fantacuzzi, S. Franceschelli, L. Giampietro, S. Masella and M. Felaco, Bioorg. Med. Chem. Lett., 2010, 20, 6495; (f) A. Patruno, S. Franceschelli, M. Pesce, C. Maccallini, M. Fantacuzzi, L. Speranza, A. Ferrone, M. A. De Lutiis, E. Ricciott and R. Amoroso, Biochim. Biophys. Acta, 2012, 1820, 2095; (g) F. T. Edelmann, Chem. Soc. Rev., 2009, 38, 2253; (h) Y. Luo, B. Knuckley, Y. H. Lee, M. R. Stallcup and P. R. Thompson, J. Am. Chem. Soc., 2006, 128, 1092; (i) Q. Dai, Y. Jiang, J.-T. Yu and J. Cheng, Chem. Commun., 2015, 51, 16645.

2 (a) J. V. Greenhill and P. Lue, Prog. Med. Chem., 1993, 30, 203; (b) S. D. Guile, L. Alcaraz, T. N. Birkinshaw, K. C. Bowers, M. R. Ebden, M. Furber and M. J. Stocks, J. Med. Chem., 2009, 52, 3123; (c) M. Y. Lee, M. H. Kim, J. Kim, S. H. Kim, B. T. Kim, I. H. Jeong, S. Chang and S. Y. Chang, Bioorg. Med. Chem. Lett., 2010, 20, 541; (d) G. Brasche and S. L. Buchwald, Angew., Chem. Int. Ed., 2008, 47, 1932;
Angew. Chem., 2008, 120, 1958; (e) S. Caron, L. Wei, J. Douville and A. Ghosh, J. Org. Chem., 2010, 75, 945; (f) R. Khan, M. Arfan, J. Mahmood, S. Anjum and M. I. Choudhary, Chin. Chem. Lett., 2010, 21, 905; $(g)$ J. R. Harjani, C. Liang and P. G. Jessop, J. Org. Chem., 2011, 76, 1683; (h) M. A. McGowan, C. Z. McAvoy and S. L. Buchwald, Org. Lett., 2012, 14, 3800; (i) Y. F. Wang, X. Zhu and S. Chiba, J. Am. Chem. Soc., 2012, 134, 3679; J. Am. Chem. Soc., 2012, 134, 11980; (j) J. E. Taylor, S. D. Bull and J. M. J. Williams, Chem. Soc. Rev., 2012, 41, 2109; (k) M. Macczka, J. Janczak, M. Trzebiatowska, A. Sieradzki, S. Pawlus and A. Pikul, Dalton Trans., 2017, 46, 8476; (l) J. Barker and M. Kilner, Coord. Chem. Rev., 1994, 133, 219; S. H. Oakley, D. B. Soria, M. P. Coles and P. B. Hitchcock, Dalton Trans., 2004, 537; F. T. Edelmann, Adv. Organomet. Chem., 2008, 57, 183.

3 (a) V. A. Mamedov, N. A. Zhukova, V. V. Syakaev, A. T. Gubaidullin, T. N. Beschastnova, D. I. Adgamova, A. I. Samigullina and S. K. Latypov, Tetrahedron, 2013, 69, 1403; (b) D.-H. Wang, Y.-X. Yang, Y.-Q. Yang, T.-C. Zhao, X. Wu and S.-K. Wang, Sci. Bull., 2006, 51, 785; (c) A. Tantawy, A. E Barghash, S. Badr and R. Gomaa, Heterocycl. Commun., 2013, 19, 125; (d) N. R. Perl and J. L. Leighton, Org. Lett., 2007, 9, 3699; (e) J.-L. Du, L.-J. Li and Y.-F. Li, Inorg. Chem. Commun., 2005, 8, 246; $(f)$ H. C Chang, B. C. Son, G. Y. Song, J. Y. Shin, C. S. Ha, H. S. Suh and I. Kim, Macromol. Res., 2013, 21, 118; $(g)$ V. A. Mamedov, A. M. Murtazina, N. A. Zhukova, T. N. Beschastnova, Il. K. Rizvanov and S. K. Latypov, Tetrahedron, 2014, 70, 7567.

4 (a) B. Wang, H.-F. Du and Y. A. Shi, Angew. Chem., 2008, 120, 8348; Angew. Chem., Int. Ed., 2008, 47, 8224; (b) J. J. Neumann, S. Rakshit, T. Droge and F. Glorius, Angew. Chem., 2009, 121, 7024; Angew. Chem., Int. Ed., 2009, 48, 6892; (c) Y. Tan and J. F. Hartwig, J. Am. Chem. Soc., 2010, 132, 3676; (d) K. Shin, H. Kim and S. Chang, Acc. Chem. Res., 2015, 48, 1040; (e) J. Jiao, K. Murakami and K. Itami, ACS Catal., 2016, 6, 610; (f) W. Choi, J. Kim, T. Ryu, K.-B. Kim and P. H. Lee, Org. Lett., 2015, 17, 3330; $(g)$ C. Du, P.-X. Li, X.-J. Zhu, J.-N. Han, J.-L. Niu and M.-P. Song, ACS Catal., 2017, 7, 2810; (h) Y. Park, Y. Kim and S. Chang, Chem. Rev., 2017, 117, 9247; (i) S. B. Lafollée, R. Gil, D. Prim and J. Hannedouche, Molecules, 2017, 22, 1901; (j) Y. N. Timsina, B. F. Gupton and K. C. Ellis, ACS Catal., 2018, 8, 5732.

5 (a) G. Rousselet, P. Capdeviclle and M. Maumy, Tetrahedron Lett., 1993, 34, 6395; (b) V. Y. Kukushkin and A. J. L. Pombeiro, Chem. Rev., 2002, 102, 1771; (c) J.-F. Wang, F. Xu, T. Cai and Q. Shen, Org. Lett., 2008, 10, 445; (d) S. Ueda and H. Nagasawa, J. Am. Chem. Soc., 2009, 131, 15080; (e) J. Savmarker, J. Rydfjord, J. Gising, L. R. Odell and M. Larhed, Org. Lett., 2012, 14, 2394; (f) J. Rydfjord, F. Svensson and A. Trejos, Mats Larhed, Chem.Eur. J., 2013, 19, 13803.

6 (a) A. T. Khan, R. Sidick Basha, M. Lala and M. H. Mir, RSC Adv., 2012, 2, 5506-5509; (b) A. Kumar, D. Saxena and M. K. Gupta, Green Chem., 2013, 15, 2699; (c) T. Vlaar, 
E. Ruijter, B. U. W. Maes and R. V. A. Orru, Angew. Chem., Int. Ed., 2013, 52, 7084; (d) P. Mampuys, Y.-P. Zhu, T. Vlaar, E. Ruijter, R. V. A. Orru and B. U. W. Maes, Angew. Chem., Int. Ed., 2014, 15, 12849; (e) Q. Dai, Y. Jiang, J.-T. Yu and J. Cheng, Chem. Commun., 2015, 51, 16645; (f) F.-X. Zhu, Y.-H. Li, Z.-C. Wang and X.-F. Wu, Chem.-Eur. J., 2016, 22, 7743; Z.-Y. Gu, C.-G. Liu, S.-Y. Wang and S.-J. Ji, J. Org. Chem., 2017, 82, 2223.

7 (a) I. Bae, H. Han and S. Chang, J. Am. Chem. Soc., 2005, 127, 2038; (b) S. Brase, C. Gil, K. Knepper and V. Zimmermann, Angew. Chem., Int. Ed., 2005, 44, 5188; (c) X.-L. Xu, X.-N. Li, L. Ma, N. Ye and B.-J. Weng, J. Am. Chem. Soc., 2008, 130, 14048; (d) E. J. Yoo, M. Ahlquist, I. Bae, K. B. Sharpless, V. V. Fokin and S. Chang, J. Org. Chem., 2008, 73, 5520; (e) X.-L. Xu, Z.-C. Ge, D.-P. Cheng, L. Ma, C.-S. Lu, Q.-F. Zhang, N. Yao and X.-N. Li, Org. Lett., 2010, 12, 897; (f) M. Aswad, J. Chiba, T. Tomohiro and Y. Hatanaka, Chem. Commun., 2013, 49, 10242; (g) G. Murugavel and T. Punniyamurthy, J. Org. Chem., 2015, 80, 6291; (h) S. Y. Chow and L. R. Odell, J. Org. Chem., 2017, 82, 2515.

8 (a) C. Zhang, L. Zhang and N. Jiao, Adv. Synth. Catal., 2012, 354, 1293; (b) G. Martinez-Ariza, M. Ayaz and C. Hulme, Tetrahedron Lett., 2013, 54, 6719; (c) A. Kumar, N. Battini, R. R. Kumar, S. Athimoolam and Q. N. Ahmed, Eur. J. Org. Chem., 2016, 3344; (d) G. Martinez-Ariza, N. McConnell and C. Hulme, Org. Lett., 2016, 18, 1864; (e) X.-X. Liu, Z.-Y. Wu, Y.-Q. He, X.-Q. Zhou, T. Hu, C.-W. Ma and G.-S. Huang, Adv. Synth. Catal., 2016, 358, 2385; (f) C. Chen, M.-H. Zhu, L.-H. Jiang, Z.-B. Zeng, N.-N. Yi and J.-N. Xiang, Org. Biomol. Chem., 2017, 15, 8134; (g) J. Zhang, X. Wu, Q. Gao, X. Geng, P. Zhao, Y.-D. Wu and A.-X. Wu, Org. Lett., 2017, 19, 408; (h) L. Dutta and P. J. Bhuyan, Tetrahedron, 2018, 74, 5770 .

9 The Amide Linkage: Structural Significance in Chemistry, Biochemistry and Materials Science, ed.A. Greenberg, C. M. Breneman and J. F. Liebman, Wiley, New York, 2003.

10 (a) Q. Zhu and Y.-X. Lu, Org. Lett., 2010, 12, 4156; (b) Y. Jiao and C.-S. Cho, Appl. Organomet. Chem., 2015, 29, 372; (c) W. Phakhodee, S. Wangngae, N. Wiriya and M. Pattarawarapan, Tetrahedron Lett., 2016, 57, 5351; (d) W. Phakhodee, S. Wangngae and M. Pattarawarapan, J. Org. Chem., 2017, 82, 8058; (e) W. A. Loughlin, I. D. Jenkins and M. J. Petersson, J. Org. Chem., 2013, 78, 7356; (f) Y.-P. Zhu, Z. Fei, M.-C. Liu, F.-C. Jia and A.-X. Wu, Org. Lett., 2013, 15, 378; $(g)$ N. T. Jui and S. L. Buchwald, Angew. Chem., Int. Ed., 2013, 52, 11624; (h) V. Ganesh, D. Sureshkumar, D. Chanda and S. Chandrasekaran, Chem.-Eur. J., 2012, 18, 12498.

11 X.-Q. Liu, H.-F. Yue, J.-Q. Jia, L. Guo and M. Rueping, Chem.Eur. J., 2017, 23, 11771.

12 (a) J.-H. Xu, Q. Jiang and C.-C. Guo, J. Org. Chem., 2013, 78, 11881; (b) Q. Jiang, B. Xu, A. Zhao, J. Jia, T. Liu and C.-C. Guo, J. Org. Chem., 2014, 79, 8750; (c) Q. Jiang, J.-Y. Wang and C.-C. Guo, J. Org. Chem., 2014, 79, 8768; (d) M.-Z. Zhang, Q.-H. Guo, W.-B. Sheng and C.-C. Guo, Adv. Synth. Catal., 2015, 357, 2855; (e) B. Xu, Q. Jiang, A. Zhao, J. Jia, Q. Liu, W.-P. Luo and C.-C. Guo, Chem. Commun.,
2015, 51, 11264; (f) Y.-F. Liu, Y.-Q. Hu, Z.-Z. Cao, X. Zhan, W.-P. Luo, Q. Liu and C.-C. Guo, Adv. Synth. Catal., 2018, 360, 2691.

13 (a) W. Wei, Y. Shao, H.-Y. Hu, F. Zhang, C. Zhang, Y. Xu and X.-B. Wan, J. Org. Chem., 2012, 77, 7157; (b) W.-P. Mai, H.-H. Wang, Z.-C. Li, J.-W. Yuan, Y.-M. Xiao, L.-R. Yang, P. Mao and L.-B. Qu, Chem. Commun., 2012, 48, 10117; (c) J. Zhang, Y. Wei, S.-X. Lin, F.-S. Liang and P.-J. Liu, Org. Biomol. Chem., 2012, 10, 9237; (d) Q. Zhao, T. Miao, X.-B. Zhang, W. Zhou and L. Wang, Org. Biomol. Chem., 2013, 11, 1867; (e) H.-L. Huang, G.-Q. Yuan, X.-W. Li and H.-F. Jiang, Tetrahedron Lett., 2013, 54, 7156; $(f) \mathrm{X} . \mathrm{Wu}$, Q.-H. Gao, S. Liu and A.-X. Wu, Org. Lett., 2014, 16, 2888; (g) W.-B. Liu, S.-S. Xu, C. Chen and Z.-B. Zhu, ChemistrySelect, 2016, 3, 612; (h) D. Wang, K. Zhang, L.-H. Jia, D.-T. Zhang, Y. Zhang and Y.-J. Cheng, Org. Biomol. Chem., 2017, 15, 3427.

14 (a) J. Muzart, Tetrahedron, 2009, 65, 8313; (b) S. H. Cho, J. Y. Kim, S. Y. Lee and S. Chang, Angew. Chem., Int. Ed., 2009, 48, 9127; (c) J. Wang, J.-T. Hou, J. Wen, J. Zhang and X.-Q. Yu, Chem. Commun., 2011, 47, 3652; (d) Y.-M. Li, Y.-S. Xie, R. Zhang, K. Jin, X.-N. Wang and C.-Y. Duan, J. Org. Chem., 2011, 76, 5444; (e) S.-T. Ding and N. Jiao, Angew. Chem., Int. Ed., 2012, 51, 9226; (f) H. Wang, L.-N. Guo and X.-H. Duan, Org. Biomol. Chem., 2013, 11, 4573; (g) B.-N. Du, B. Jin and P.-P. Sun, Org. Biomol. Chem., 2014, 12, 4586; (h) W.-B. Liu, C. Chen and H.-L. Liu, Beilstein J. Org. Chem., 2015, 11, 1721; (i) P. B. Thale, P. N. Borase and G. S. Shankarling, RSC Adv., 2016, 6, 52724; (j) W.-B. Liu, C. Chen and P. Zhou, ChemistrySelect, 2017, 2, 5532.

15 (a) H.-Z. Li, W.-J. Xue and A.-X. Wu, Tetrahedron, 2014, 70, 4645; (b) N. Mupparapu, S. Khan, S. Battula, M. Kushwaha, A. P. Gupta, Q. N. Ahmed and R. A. Vishwakarma, Org. Lett., 2014, 16, 1152; (c) A. K. Padala, N. Mupparapu, D. Singh, R. A. Vishwakarma and Q. N. Ahmed, Eur. J. Org. Chem., 2015, 3577; (d) X. Wu, Q.-H. Gao, X. Geng, J.-J. Zhang, Y.-D. Wu and A.-X. Wu, Org. Lett., 2016, 18, 2507; (e) P. Natarajan, Manjeet, N. Kumar, S. Devi and K. Mer, Tetrahedron Lett., 2017, 58, 658.

16 (a) W. Hub, S. Schneider, F. Doerr, J. D. Oxman and F. D. Lewis, J. Am. Chem. Soc., 1984, 106, 701; (b) J. C. Scaiano, S. Garcia and H. Garcla, Tetrahedron Lett., 1997, 38, 5929; (c) O. Brede, A. Maroz, R. Hermann and S. Naumov, J. Phys. Chem. A, 2005, 109, 8081; (d) A. Grirrane, A. Corma and H. Garcia, Science, 2008, 322, 1661; (e) C. Zhang and N. Jiao, Angew. Chem., Int. Ed., 2010, 49, 6174; $(f)$ X.-Y. Chen, X.-Y. Wang, Y.-X. Sui, Y.-Z. Li, J. Ma, J.-L. Zuo and X.-P. Wang, Angew. Chem., Int. Ed., 2012, 51, 11878; (g) X.-Y. Chen, X.-Y. Wang, Y.-X. Sui, Y.-Z. Li, J. Ma, J.-L. Zuo and X.-P. Wang, Angew. Chem., Int. Ed., 2014, 53, 943; (h) M. R. Talipov, J. S. Hewage, S. V. Lindeman, J. R. Gardinier and R. Rathore, Angew. Chem., Int. Ed., 2014, 53, 938; P. Nalawade, S. Naumov and S. Kapoor, J. Phys. Org. Chem., 2015, 28, 2. (i) S.-W. Zhang, W.-Q. Wang, S. Liu, Y.-X. Sui, Z.-C. Zhang, G.-W. Tan, 
Q. Sun and X.-P. Wan, Sci. China: Chem., 2017, 60, 1439, DOI: 10.1007/s11426-017-9096-7.

17 D. Wang, K. Zhang, L.-H. Jia, D.-T. Zhang, Y. Zhang, Y.-J. Cheng, C. Lin and B. Wang, Org. Biomol. Chem., 2017, 15, 3427.

18 (a) Z.-J. Liu, J. Zhang, S.-L. Chen, E.-B. Shi, Y. Xu and X.-B. Wan, Angew. Chem., Int. Ed., 2012, 51, 3231; (b) L. Y. M. Eymann, A. G. Tskhovrebov, A. Sienkiewicz,
J. L. Bila, I. Živković, H. M. Rønnow, M. D. Wodrich, L. Vannay, C. Corminboeuf, P. Pattison, E. Solari, R. Scopelliti and K. Severin, J. Am. Chem. Soc., 2016, 138, 15126; (c) L.-W. Zheng, M. Griesser, D. A. Pratt and M. M. Greenberg, J. Org. Chem., 2017, 82, 3571; (d) D. Shimizu, K. Furukawa and A. Osuka, Angew. Chem., Int. Ed., 2017, 56, 7435. 